Oñati Socio-legal Series, v. 8, n. 6 (2018) - State of Exception, Law and Economy: A socio-legal approach to the economic of exception in an era of crisis ISSN: 2079-5971

\title{
The permanent state of exception in the southern periphery of Europe
}

I GNASI BERNAT*

Bernat, I., 2018. The permanent state of exception in the southern periphery of Europe. Oñati Socio-legal Series [online], 8 (6), 925-949. Received : 29-10-2018 ; Accepted : 2711-2018. Available from: https://doi.org/10.35295/osls.iisl/0000-0000-0000-0971

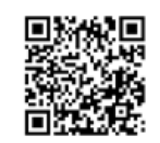

\begin{abstract}
The permanent crisis in the southern periphery of Europe has been deep socially, politically and economically. In order to contain it the sovereign power has shown all its majesty. The state of exception has been the mechanism deployed to introduce the political decision within the legal framework. Departing from Agamben's understanding of this mechanism of power, the paper directs its attention to several dimensions in Portugal, Italy, Greece and Spain. That is, the financial crisis, the corporate impunity and the migrants death have been handled to silence the potentia to disrupt the ongoing capitalist and colonial regime of power. Actually, the state of exception has secured the current status quo, but also has intensified the ongoing regime of power. This dispositive is always accompanied by a legitimising discourse which essentialises and otherises these countries. After observing how this mechanism has operated in Southern Europe, the paper turns on discussing how to abandon this regime of power.
\end{abstract}

\section{Key words}

State of Exception; permanent crisis; European regime of power; Southern Europe

\section{Resumen}

La crisis permanente en la periferia sur de Europa ha sido profunda. El estado de excepción ha sido el mecanismo desplegado para introducir la decisión política en el marco jurídico. Partiendo de la interpretación de este mecanismo de poder por parte de Agamben, el artículo se fija en varias dimensiones en Portugal, Italia, Grecia y España. Es decir: la crisis financiera, la impunidad de las grandes empresas y la muerte de migrantes han sido gestionadas para acallar la potentia para perturbar el régimen de poder capitalista y colonial. En realidad, el estado de excepción ha reforzado el status quo, pero también ha intensificado el poder establecido. Este dispositivo siempre viene acompañado de un discurso legitimizador que esencializa y alteriza esos países. Tras observar cómo este mecanismo ha funcionado en el sur de Europa, se propone un debate sobre cómo abandonar ese régimen de poder.

\footnotetext{
* Ignasi Bernat is a sociologist and critical criminologist who has been lecturing in universities of Spain and UK. Contact details: Universidad de Girona, Carrer Universitat de Girona s/n 17071, Facultat de Dret. Email address: ignasi.bernat@gmail.com. ORCID: http://orcid.org/0000-0003-4456-3764
}

\section{(cc) EY-NC-ND}

Oñati International Institute for the Sociology of Law

Antigua Universidad s/n - Apdo.28 20560 Oñati - Gipuzkoa - Spain

Tel. (+34) 943783064

E: opo@iisj.es W: http://opo.iisj.net 


\section{Palabras claves}

Estado de excepción; crisis permanente; régimen de poder europeo; sur de Europa 


\section{Table of contents / Índice}

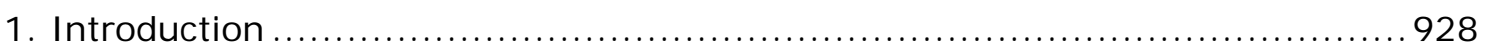

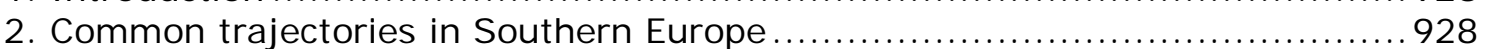

3. The paradigm of the State of Exception ...................................... 930

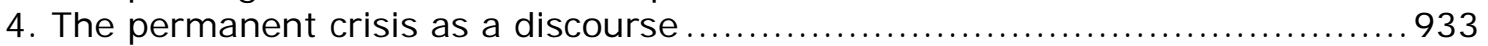

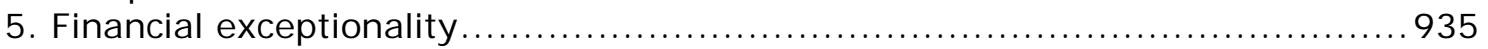

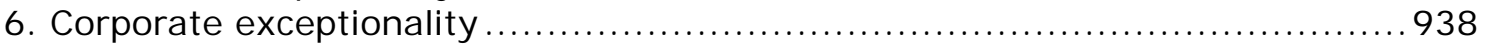

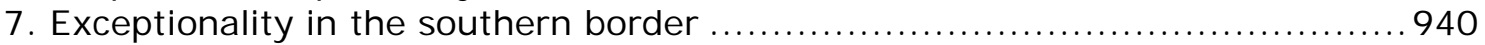

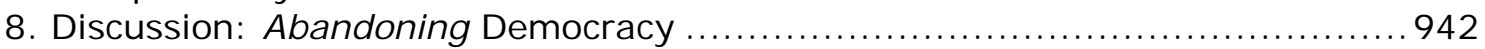

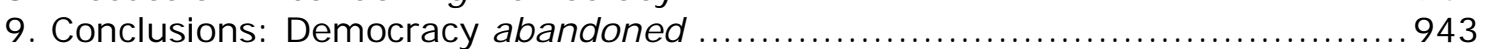

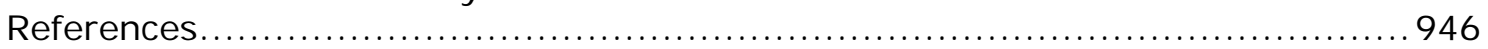


The tradition of the oppressed teaches us that the 'state of exception' in which we live is the rule. We must arrive at a concept of history which reflects this. Then it will become clear that our mission is the introduction of a genuine state of exception; and our position in the struggle against Fascism will benefit from it. (Walter Benjamin)

\section{I ntroduction}

This article deals with the ongoing crisis in the southern periphery of the European Union from the perspective of the state of exception as a mechanism of sovereign power (Agamben 2004). This governmental mechanism has become increasingly important in the present situation in the handling of complex situations when power and sovereignty are in dispute in the midst of a crisis both unexpected and imposed. An unexpected crisis which interrupts the rhythms of capital accumulation and one which is imposed on the working classes in the countries in the south of the EU. From this approach we will analyse three dimensions of this permanent crisis (Agamben 2014) which has demolished the old certainties and consensuses and led to the establishment of a new political period consolidating the structure of economic and political power in the EU. If sovereign power retains for itself the capacity to decide about the exception, we will have to analyse the management of moments of crisis in order to understand its mode of operation. Thus, it will be seen how sovereign debt, corporate impunity and the deaths at the southern border are managed so as to re-establish that which the crisis brought into question. A study of these three phenomena makes evident the limits of democracy within the EU, where the financialization of the economy has hollowed out previously established social rights while taking control of regulation and law. Suddenly, parliamentary sovereignty has become an illusion guaranteeing the corporate rhythm of accumulation (Tombs and Whyte 2015) and the relationship between the centre and periphery (Lapavitsas 2013), while migrants meet their deaths trying to reach fortress Europe (Mbembe 2011). Nevertheless, the sovereign decision is taken outside the countries on the southern periphery of EU (Portugal, Italy, Greece and Spain), given their subordinate position in the European power structure. The subordinate position of these countries within this regime creates an area of legal and political uncertainty which takes us back to the three dimensions of the permanent state of exception: sovereign debt, corporate impunity and the negation of rights to migrants. In order to understand the management of this permanent crisis critically it will be necessary to displace the history of the European Union from the success of its geoeconomic centre (Karmy 2016) and account for history of the continuing peripheralization of the south in the EU. It involves denaturalising the supremacy of the centre of EU so as to historicise the different forms of oppression, situating them in their historical context and examining their construction and consolidation. In order to do so this paper will discuss the paradigm of the state of exception before interrogating the three dimensions of exceptionality: financial, corporate and migration. To conclude the paper will discuss whether we should abandon democracy and whether democracy has been abandoned. The next section of the paper will show the commonalities between these four countries to justify the collective analysis that it being proposed.

\section{Common trajectories in Southern Europe}

Although the acronym PIGS is probably used most often to refer to Ireland rather than to Italy, for analytical purposes of this article, I shall try to explain here why Italy can be included within the Southern European periphery along with Portugal, Greece and Spain. Even when today Portugal has a leftist government trying to defy the most tough austerity policies it is still far from challenging the European regime of power (Taibo 2018). Indeed, these four countries make up EU's southern corridor. Moreover, they are historically bound as the north of the Mediterranean, with a long shared history. Although it is recognised that there is also another European periphery, the Central and East periphery of the EU (Krugman 2012, Panayotov 2017) the focus of this paper is on the southern periphery. This short contemporary 
historical summary seeks to establish a joint genealogy ranging from the 1930s to the present day. In the 1930s the four countries fell to fascism. "The Cold War was an instrument of social control" (Fontana 2011). Anti-communism marked an era in which international relations played a key role in setting the political direction in these four countries. At the same time, from the end of the 1950s onwards the four countries became cheap labour for the western north of the second post-war European miracle. Greece, Portugal and Spain barely enjoyed ten years of welfare when they came out of their various fascist regimes, as this model was coming to an end in the 1980s. On the other hand, Italy was able to benefit more from this model both in terms of time and quality. It was a model based on strong macroeconomic growth. In this growth environment, the EU's market expansion was a positive development, together with a number of public and social policies aimed at redistributing this wealth (Amin 1997). European aid and subsidies to the most disadvantaged regions had a supporting but not decisive effect. Once economic growth slowed this integration of peripheral regions proved to have devastating effects (Amin 1997). It is clear that the south of the continent is immersed in uneven development (Amin 1986) within a "German Europe" (Amin 1997, Krugman 2012, Lapavitsas 2013). Since the nineties, all four countries have been ruled through neoliberalism and accumulation by dispossession, while corruption has been a constant throughout this period. Every effort for a profound social transformation has been violently thwarted with coups d'état and with the extreme right-wing abandoning democracy to privilege capitalism, ensuring impunity for corporations. Today they are the gendarme of the Southern European border, with a politics of death, termed "necropolitics", which causes thousands of casualties.

After the Second World War, Greece fell under the control of the British, who had in this country their command of Mediterranean operations and from there over the Middle East. King George II was exiled in London due to his collaboration with Metaxas' reactionary and fascistic dictatorship (1936-1941). While Papandreou's exile government in Cairo decided to demobilize the communist and national liberation guerrillas, the British took control of the country. Under Churchill's orders, "white terror" was imposed to wipe out communists and leftists by British soldiers and extreme right-wing groups who had collaborated with the Nazis. In 1946 elections were held but without the participation of the left as 40,000-50,000 leftists were being held in prison and in concentration camps (Fontana 2011). Nazi collaborators went unpunished while the left was persecuted. The civil war lasted until 1949, and with the help of British and Americans the right wing controlled the country, which joined NATO in 1952. The monarchy was restored while a series of inefficient and corrupt governments left the country mired in poverty and hunger. Instability lasted until the mid-1960s, the left was still persecuted, and, on the pretext of a left-wing coup attempt, the military staged a new coup in 1967 . The country came under the dictatorship of a military junta. The dictatorship of the colonels ended in 1974, months after the demise of the Portuguese dictatorship.

From 1933 to 1970 Portugal was ruled by Oliveira Salazar and later by Caetano until April 25, 1974. The Portuguese regime was a proto-fascist autarchy with few political and civil rights in which the left-wing opposition was systematically persecuted. The country did not enter the Second World War as it struck a balance with the allies offering the establishment of military bases to the USA, but by allowing the Nazis to move freely around the country. This led to some economic growth and stability during the 1940s, which was also due to the Marshall Plan. This also allowed the country to gain some international recognition in the 1950s, especially from the United States as a founding member of NATO, when anti-communism outweighed democracy. The Carnation Revolution (1974) put an end to the dictatorship, the longest in Europe and one which refused to lose its African colonies of Angola and Mozambique. It was precisely the colonial war that caused a great deal of discontent among the military who brought down the dictatorship with the economic problems of the oil crisis (Taibo 2018). At that time Ford and Kissinger tried to convince an 
already decrepit Franco to intervene in Portugal in order to prevent the communists from rising to power. The United States feared the arrival of a communist party to a NATO government (Fontana 2011).

In Spain the coup d'état and the subsequent civil war resulted in a fascist dictatorship as a legacy along with a large number of dead, disappeared and exiles. The fascist regime did not enter the Second World War due to its precarious economic and human situation, thus sparing the intervention of allied forces in the country. The country was left in a dreadful situation with an autarchic economy and with a heinous persecution of the left. It allowed the old oligarchy and a modest bourgeoisie to preserve their privileges and received the explicit support throughout the regime from the Catholic Church. In the 1950s, the regime signed a concordat with the Vatican and reached an agreement with Eisenhower for international recognition thanks to the establishment of American bases in Spain at the height of the Cold War (Vilar 1984). It was not until Franco's death in 1975 that a period of political transition began, marked by social and trade union mobilization, but also by extreme rightwing violence that ended with the approval of a liberal and pluralist constitution. Thus ended a fierce dictatorship that ruled with an iron fist an impoverished country, with low levels of growth, high political repression and much corruption.

After the defeat of fascism and the death of Mussolini (1922-45) and with a new social pact between capital and labour I taly was able to board the train of the welfare state albeit always with a much more rural and less industrialized south that continued to be an exporter of cheap labour to the rest of north-western Europe. Certainly, the post-war Italian situation was not the same, as Mussolini had died in a public square, but there were some political elements that paralleled the rest of Southern Europe. In fact, the CIA already played an important role in the 1948 election. The $\mathrm{ClA}$ created various organizations to launder 10 million dollars and fund Christian democracy and other likeminded organizations in order to fight the Communist Party (Fontana 2011). The Vatican spurred the turn to the right of Christian democracy and set out to finish with the work of antifascism. With the help of the Marshall Plan, economic blackmail and anti-communist propaganda, the advance of the 'red threat' was successfully halted. In fact, the Vatican defended the excommunication of those defending communism, whilst the $\mathrm{Cl}$ A created the Gladio, a secret organisation to control Italian politics, resorting as well to political violence and terrorism. In the 70's we will witness the turn towards Eurocommunism, which will imply a progressive distancing from the USSR and a "historic compromise" of collaboration with the rest of the democratic parties in an era marked by the strength of the extreme left as well as by the violence and impunity of the extreme right (Balestrini and Moroni 2006), which had as its objective to stop the advance of the communist party. The US continued to finance both political corruption and the extreme right. The state responded to the extreme left with emergency criminal laws that would end up dismantling a great number of civil liberties, as well as the radical left, and thwarting the coming to power of the historic compromise. From there followed the flood of corruption and cynicism of Christian democracy and Socialist Party with Andreotti and Craxi as the icons of an era that ended up promoting Berlusconi's arrival in power.

\section{The paradigm of the State of Exception}

We currently find different meanings in the everyday, legal and academic use of the concept of "state of exception". In fact, this concept is present in many of the legal constitutions of modern states. In this definition, the state of exception would be the legal institute that would allow the state to temporarily suspend the legal order in order to ensure its continuity or to seek its re-establishment in a time of emergency. The academic notion of a state of exception is on the rise thanks to the political philosophy of the Italian philosopher Giorgio Agamben, who has placed it at the centre of the current debate on the exercise of power and sovereignty even there are 
also some criticisms to it. However, the origins of the concept go back to the work of Carl Schmitt (1991) and his definition of politics as art of telling friends from enemies.

Schmitt's work developed mainly in the interwar period in Europe, a most propitious time to comprehend the crises that the liberal constitutional governments were undergoing, in the face of the rise of fascism and communism, particularly in the Weimar Republic (Guareschi and Rahola 2011). Schmitt's works are influenced by and are in dialogue with Walter Benjamin's work and in particular with his notion of "pure violence" (Benjamin 2010), a type of violence that is not capable of preserving the law but of deposing and suppressing it (Guareschi and Rahola 2011). Schmitt became the great thinker of the state of exception and sovereign power as mechanisms of power, but also as limits to liberal democracy. The link between law and power in sovereign decision-making was a central element in his analysis. According to Schmitt, sovereignty and state of exception intertwine, as sovereignty is determined by the capacity to decide on the exception. "The sovereign is he who decides on the state of exception" (Schmitt 2009), the one who is capable of bringing about a total suspension of the law. The sovereign's decision on the state of exception seals off the realm of political action by framing an antagonistic space that constitutes the "us" and, above all, who the others are. Or to put it in Schmitt's words, between friends and enemies (Schmitt 1991). Sovereignty sanctions the use of legitimate violence. In Schmitt, the state of exception is the legitimate use of force to contain a state of necessity, a situation that threatens to overwhelm the regime of the constituted power. This state of necessity cannot be known a priori and places the state of exception in a situation of exteriority to the law, a state of indetermination that is always in a legally blurred area. Thus, the sovereign decision on the state of exception is constituted as a genuine exercise of political power. The sovereign will transcend legality itself. The liberal rule of law is suspended by the state of exception (Dussel 2016). The sovereign decision is the act that marks the closure of the political framework, putting an end to the democratic game. It introduces the limit of what liberal democracy can withstand and it shows its unsolvable contradictions. Ultimately, the law serves to contain social relations. We find a close relationship between power, violence and law. It is the sovereign who decides what poses a threat to the social order that must not be tolerated. In this sense, it establishes an enemy to be fought while introducing the state of war into the civil body. With this act of force of law and political force, the decision on the state of exception lets us map the democratic limits and reveal the political geography of (sovereign) power. In Schmitt, then, the sovereign decision, starting from the state of necessity, allows us to observe how the law is a source of legitimization of political violence, which, despite not having a direct reference in the law, is legitimized through that very same law. In other words, the sovereign is external to the legal system, but his decision has the power to legally suspend the rule (Agamben 2004). It is this ambiguous relationship of inclusion and exclusion of violence that makes the state of exception such an efficient power device. In this ambiguous terrain between law and politics, it is more necessary than ever for discourses and practices to have a legitimacy that allows the extra-legal practices of the state of exception. The political violence of the sovereign requires discursive practices that legitimize his actions. This is an obvious contradiction as the force used to guarantee the survival of the law is always implemented resorting to forms that are not legal. This conservative violence of the law and of constituted power is invariably constitutive of a less democratic regime as the sovereign hoards and legitimizes his power while he constrains the realm of political action. The state of exception is an expression of the conservative violence of law (Schmitt 1991). It is a violence that perpetuates the law but destroys the rights.

Agamben has taken on the task of updating the paradigm of the state of exception in recent years, starting from the work of Schmitt and also that of Benjamin, showing how sovereign power operates at present times. His analysis of our contemporary era starts off from the assumption of the depoliticization of political life and the 
continued recourse to the state of exception as a mechanism of power which pervades contemporary political rationality. That is to say, in Agamben we see how the device of power represented by the state of exception has become increasingly detached from its referential state of necessity linked to public disorder, civil wars or external threats and has become a keystone of the current logic of government. This shift in the use of the state of exception has been accompanied by a growing force on the part of the executive branch which has shifted the legislative branch from its central role. This conservative logic presupposes that the law-maker's role is impractical or sometimes counterproductive in solving the complex problems of the contemporary world. In Agamben (2004) we can see that the state of exception is less and less a temporary suspension of the current legal order; it is no longer that legally blurred temporary response to re-establish the threatened law. On the contrary, the author warns us that we are moving towards a new paradigm where the state of exception has lost its temporary nature and is now a permanent state of exception. We are witnessing its "generalization and radicalization" (Lemke 2011). The exception becomes the norm. The state of exception is a power mechanism, a sovereign power's government technique in itself. In effect, the state of exception understood as the sovereign's response in times of war, public disorder or political violence where constitutional rights were temporarily suspended is losing centre stage. We are moving, says Agamben, towards a scenario where the executive power is taking on more and more powers to respond to "situations of emergency or crisis". Thus, the state of exception is gradually being defined as a means of responding to a wide range of new situations, such as natural disasters, but above all economic crises. The sovereign uses the state of exception as a more efficient way of responding to certain situations than the rule of law itself. The state of exception represents an intensification of normality, a power dispositive that secures the survival of the very power regime that might be challenged in times of crisis. In Agamben's opinion, we are witnessing a schism in the state of necessity addressed to enforcing the state of exception, which has now become another way of fulfilling the government's policing role. A policing role always linked to the maintenance of order and the discretionary use of violence, but with law as a presumed point of reference. According to Agamben, we are in the process of moving towards a new paradigm of political action where the expression of sovereign power is diluting the separation between law, justice and politics. The path towards the technification of political life under efficiency criteria is the central element of depoliticization. The state of exception as a governmental technique seems to be capturing politics.

The crystallization of the state of exception entails confusion between law and fact, between inside and outside, where law and exception become blurred (Campesi 2011). The state of exception comes central to contemporary political strategies, the difference between inside and outside, between law and fact enter an indistinguishable zone. As a result, the system of liberal democratic law does not provide any substantial alternative to dictatorships. These political regimes exacerbate the political trends already present in liberal democracies. The difference is one of intensity, but when the sovereign power becomes threatened by the popular power it reveals itself again in all its splendour and brutality. In this sense, inclusion in the political community is achieved through the exclusion and denial of certain civil and political rights. This means that a distinction is made between the person and the granted rights; it is not direct but mediated by the sovereign power. What is interesting is that Agamben places biopolitical mechanisms at the centre of contemporary political rationality, in connection with sovereign power. In this way, biopolitics is placed at the centre of sovereign power (Lemke 2011). Agamben shifts Schmitt's distinction between friend and enemy to the split between mere bare life and political existence. The distinction between bare life (zoé) and political existence (bios) represents the difference between natural human beings and the legal existence of the person. This differentiation is what allows for the possibility of denying rights to people who are denied personal rights. Law and life unite in the exception as a sovereign power device (Fleisner 2015). That portrays the continuity 
between totalitarianism and democracy, "a disturbing affinity". At the origin of all politics we do not find a distinction between friend and enemy but a line that separates and establishes a space that is not protected by law. The sovereign can deny rights within the field of his domain those who he wants to. Therefore, once excluded from the protection of the law these people are abandoned, reduced to mere living bodies without rights (Agamben 1998). The state of exception becomes the way to introduce violence into the legal system, a form of violence that can take different shapes. Thus, the state of exception allows for the introduction of political measures that guarantee the survival of the dominating reason (Brown 2015). In other words, it facilitates the introduction of practices and strategies, plans and laws that are aimed at ensuring the continuity of the status quo.

As noted above, the notion of state of exception is not free of criticism (see also the introduction to this special issue). The main critique set out here is in relation to the sovereign. The assumption of the sovereign requires someone or something that takes the decision in a particular time and place, but this seems complicated in a globalised period when we have witnessed the lost of power of the nation-state and its rescaling in a plethora of public and private institutions (Guareschi and Rahola 2011). That is, how it is possible to locate power in a multilevel distribution of power encompassing local, national and transnational administrations and organisations. In this context, it seems more appropriate to analize power in a networked manner, whereby power arises from a number of different places that secure the reproduction of order in a more efficient and productive way (Dean 2010). Governmentality is the notion used by Foucault to express this alternative understanding of power which cannot be reduced to a single source (Guareschi and Rahola 2011). Yet as this paper will show, even after recognising this critique, the notion of the state of exception continues to be useful for understanding how in the context of the last European crisis we have witnessed the introduction of political decisions in each of these countries to save the European regime of power. Indeed, these decisions privileged the European economic and spatial arrangement against the will of the people or the legitimacy of those four nation-states (Aglietta and Brandt 2015).

The genealogy of the different measures taken will allow us to understand how legal practices are not committed to democracy, but to a regime of power. These measures that guarantee political decisions are disguised as law and legitimacy, so that the economic, political and social crisis do not overwhelm the regime of power. The state of exception makes it possible to depoliticize the crisis and disguise it as a technical or legal problem. Discursive practices are always necessary to ensure the legitimacy and hegemony of these options (permanent crisis).

\section{The permanent crisis as a discourse}

In the economic crisis and the ensuing social protests in Southern Europe we find different moments or phases. At first, we have a level of social protest that did not reach the depth it would later achieve when the revolts in the Southern Mediterranean spread to its northern neighbours. From 2011 and the second recession, the revolts against the measures adopted by the different governments, the EU and the financial institutions were widely seconded, generating a crisis of governability. Perhaps the spread of social protest is due to the fact that social protection measures no longer succeeded in alleviating the effects of the crisis, or perhaps due to the example of Arab springs or the reconstruction of the grass-roots movement. These two moments correspond to the transition from the economic crisis that began in 2008 to the sovereign debt crisis that erupted in 2011 and the corresponding measures that were taken to consolidate the different financial systems that swept away many social rights.

As a result of the serious crisis of legitimacy and hegemony of the different governments, a discursive element emerged in this battle. The discourse, as always, is important for establishing the framework of the dispute (Mignolo and Walsh 2018). 
It turns out that in times of instability whoever imposes the interpretative framework and the account of events has a great chance of obtaining political victory. In this battle to establish the narrative that would explain the situation, the notion of crisis appeared in the public sphere ad nauseam. Economic crisis, sovereign debt crisis, refugee crisis... The notion of crisis implies a rupture or a cessation of normality, it is a moment of change but always with an urgency that leaves little room for slow reflection (Campesi 2018). In this sense, crises always give rise to alarm or anxiety as they usually require exceptional measures to deal with them. Thus, out of the multiple crises, an idea emerged that we were in a permanent crisis. The idea of the permanent crisis took shape as an argument for closing certain debates and certain political possibilities and options. The discourse of the permanent crisis has revealed itself as a power mechanism in three very clear ways. In the first place, the discourse of permanent crisis serves to squash the criticisms, attempts to bring about a bond through fear that the loss of legitimacy can no longer achieve. If the crisis is not over, it is not the time to make demands that go in the direction of recovering previous welfare standards. We are not in a situation of growth or prosperity and, therefore, new measures can still be taken, or we will have to tighten our belts. All these expressions have been very common over the past few years. In this sense, it disempowers people with regard to their problems and situation, introducing a sense of submissiveness among the population.

Secondly, the discourse of the permanent crisis carries with it an implicit demand to continue taking measures to deal with the crisis. This discourse is used to legitimize the implementation of different policies, measures, plans and laws. If the crisis is not over, then measures must continue to be taken for it to subside. This is a discourse that encourages or facilitates the continued adoption of political measures to alleviate the effects of the crisis. Thus, this discourse facilitates the taking of certain measures, but also makes it difficult to take other measures that may go in the direction of recovering or expanding rights.

Thirdly, the discourse of the permanent crisis has turned out to be a power mechanism precisely because of the type of measures that have eventually been taken. The initiatives and laws adopted by the different governments of Southern Europe have gone precisely in the direction of attacking the most vulnerable sectors of their population. The vast majority of decisions taken by these governments have not been aimed at putting an end to tax havens, social dumping, free trade zones or opacity zones from which capital benefits. Nor have they gone in the direction of taxing capital transactions or profits, large fortunes or top earners. On the contrary, the vast majority of the measures adopted have involved cuts and austerity policies with regard to different social rights such as education, health, pensions or welfare benefits in a broad sense. The other flagship measure has been to raise indirect taxes such as VAT, which are known to be regressive. In the Spanish case, for instance, we find the legalisation of criminal practices such as tax fraud through a fiscal amnesty passed by the government. Indeed, we can argue that most of these measures have had a regressive outcome socially. These measures have been taken assuming that they were promoting the fostering of the economy through the recovery of profits for business and for entrepreneurs. Here it is obvious that the state function that provides legitimacy is the accumulation of capital. This shift in the way to achieve legitimacy and its overlapping with capital's interests appears as the great triumph of neoliberal reason (Brown 2015). Economic progress thus confronts and eradicates social rights. The "permanent crisis" discourse has become a central technique of governance, mechanism of power that allows an intensification of normality through the consolidation of neoliberal reason. Thus, there is nothing that can exist outside the crisis (Agamben 1998).

The permanent crisis discourse comes with a series of adjacent discourses in the public sphere. These common sense discourses are strategies to responsibilise the victims of austerity (Cooper and Whyte 2017) with the aim to silencing criticisms of austerity policies. Those discourses are based upon, in turn, an overtly classist 
discourse that attacks the "lifestyles" and "choices" of working class people (they are living above their means, have failed to save or live frugally enough, etc.). This classist discourse forgets to mention all the measures taken to ensure that working class people are forced to spend more than they earn. Thus, the need to buy many social rights in the market because of the lack of social protection (housing as its paradigmatic example) and the reduction of the purchasing power is framed by an intensification of consumerism ideology, and an aggressive consumer credit expansion that is fueled by financial institutions. Moreover, this common sense is also based upon a racist discourse that represents the peripheral countries (PIGS) as lazy and inefficient. It is for that reason that the PIGS suffered the crisis. This common sense of course ignores the real underlying power relations within the EU. Merkel's statements on the "week Greeks" were an obvious example of this racializing discourse and of the legitimising of inequalities within the EU. A modified version of this discourse locates the causes of the crisis in economic inefficiency resulting from the corruption of the political and economic elites of those countries. Without denying the corruption of these political and economic elites, it is clear that this discourse ignores the power relations within the EU and the corrupt practices in the countries of the European core (Whyte 2015). This orientalist and racist discourse within the EU works in a complex network of power/knowledge that promotes such discourses. Without that thick net of power/knowledge the sovereignty of the core over the periphery would not be sustainable (Sayyid 2017). The racism and orientalism of the centre can speak because it is assumed a rationality in its discourse which is sustained by the hierarchical violence that divides the centre and the periphery. The periphery needs the expert intervention of the centre because it cannot govern itself (Said 2002).

\section{Financial exceptionality}

This permanent crisis that is dealt with through the sovereign exception has a first example in the use of public debt as a means of managing the crisis itself. Once the public debt was created, its payment was imposed ahead of social expenditure items in different ways in the four countries we are dealing with. The repayment of credits from international creditors took precedence over the human consequences of such policies in what are known as globalization crimes (Friedrichs and Friedrichs 2002, Friedrichs 2018). The European spatial arrangement constrains state sovereignty so as to safeguard the rights of capital, to protect those who have already invested or those who might do so at a later stage (Aglietta and Brandt 2015), in order to encourage investment and accumulation (Bernat 2018).

The global recession that followed the Lehman Brothers collapse resulted in a drastic drop in revenue for eurozone countries leading to increased budget deficits. The fiscal imbalance in the budgets of peripheral countries was the result of the crisis and not its cause (Lapavitsas 2013). As the sovereign debt of peripheral EU countries rose, the bond market reacted by driving those countries out of the international bond market. Greece, Portugal, Spain and eventually Italy were dragged into a fragile situation (Lapavitsas 2012). The accumulation of sovereign debt by peripheral countries posed a great risk to the central countries, since most of that debt was intra-European and interbank (Lapavitsas 2013). In other words, a large part of the debt of the peripheral countries was owed to central European banks. This situation was the one that forced an early intervention that made the European power regime evident. The rescue intervention in the peripheral countries was intended to prevent the contagion of the banks of those countries to those of the centre of the EU, particularly Germany and France, as they faced heavy losses and funding problems (Lapavitsas 2012).

The situation in Greece is by far the most extreme in terms of debt, but nevertheless it must be noted that its sovereign debt derives mainly from private debt. Although it was dragging a significant volume of sovereign debt since the 1980s, the core of its debt came from the private debt of banks and households from the 1990s 
(Lapavitsas 2013). In the 2000s, two thirds of its sovereign debt were owed by foreigners, with a similar share in the case of Portugal. This is due to the collapse of domestic savings and the need for international financing. This appeared to be an advantage of joining the euro, which later proved to be a problem (Lapavitsas 2012). The three financial bailouts in eight years contributed 288 billion euros to the Greek economy, but under draconian conditions. Among them, to force the Greek state to have a fiscal surplus until 2060. But in addition to that, the lending terms are usurious since there is a differential of more than four points between IMF loans to Greece and the European Central Bank rate. The EU's central countries are thus pillaging their own periphery. At the same time, these bailouts make peripheral bonds unattractive and therefore, those of the centre become more attractive causing the financing cost of the regional centre to fall. But should these draconian terms not be accepted, the threat of inflicting greater pain on the populations of those countries is very present as it was when people voted oxi in the Greek referendum. In order to accept the loan money Greece had to sign a Memorandum of Understanding that imposed severe conditions of structural adjustment: labour market reforms, cuts in health care, education, pensions and many other public provisions (Georgoulas 2018). Supervision of such measures was left to the European Commission. The European institutions and the law play a fundamental role in implementing austerity measures as they intervene to leave the economy out of democratic control, introducing the legal obligation into the political measures of governments. Law and the EU are the conservative expression of the policy that we will have to abandon if we want to protect ourselves from the violence of austerity (Knox 2017). Sovereign power intervenes by introducing legal measures that shut off the political decision-making field by imposing certain economic measures (Georgoulas 2018).

Spain's public debt in 2007 was lower than that of most of its European partners, at around $40 \%$, while France or Germany were over $65 \%$ of gross domestic product (GDP) [Cutillas and Wessling 2013]. In addition, in 2006 Spain had a budget surplus (Krugman 2012). Public debt has skyrocketed due to the annual deficit, which averaged $9 \%$ between 2008 and 2012 (Cutillas and Wessling 2013). The debt interest payment went from 18,600 million euros in 2008 to 40,000 million euros in 2013, which naturally has increased the economic problems and is complicating the way out of the crisis. This deficit is mainly caused by two factors: the first is the result of the collapse of the real estate bubble that caused tax revenues to fall when economic activity came abruptly to a halt and, on the other hand, when the State assumed the private debt, and more specifically that linked to the banks and due to the decision to rescue them through capital injections, warrants and guarantees (FROB) and the purchase of toxic assets above their price (SAREB). The market coup in Spain (Bernal 2014) took place on September 2, 2011 when Article 135 of the Spanish Constitution was amended. Just ten days earlier, on 23 August, the president of the government, José Luis Rodríguez Zapatero, announced in parliament that he had reached an agreement with the leader of the opposition, Mariano Rajoy, to make such a change (El Mundo 2011).

Italy had the highest public debt after Greece in the whole of the EU, $120 \%$ of GDP in the years prior to the crisis (Lapavitsas 2012). Berlusconi's government and his finance minister Tremonti planned a $\$ 68$ trillion cut but did not manage to calm the markets. This forced his resignation and the fall of his government. Then the president of the republic, Giorgio Napolitano, with the bonuses fired instructed Monti to form a government. Monti proposes a technical cabinet as a solution to the political and economic crisis. The alleged success is a cabinet without politicians, just technicians that is accepted by the whole parliament minus the Lega Norte. Mario Monti becomes Italian Prime Minister until the end of the legislature (2011-13). The recipes of the technocratic cabinet are the ones already known and applied in all cases of austericide: labour reforms, social cuts, reduced public investment, a freeze on public employee hiring until 2014, an increase in the retirement age... all in order 
to reduce the fiscal deficit while applying for a 30,000-million-euro loan. The IMF praises the efforts and thus contains the risk premium.

At the beginning of 2011 Portuguese Prime Minister José Sócrates of the socialist party was forced to admit that Portugal would be unable to repay Portugal's high public debt. The three rating agencies Standard's and Poor, Fitch and Moody's lowered the quality of the Portuguese debt that paid up to $10 \%$ interest on its fiveyear bonds. The government resigned in March as it was unable to execute its economic adjustment plans, but financial pressure continued to mount. Market pressure represented in the refusal to buy treasury bonds and the rising risk premium led to a request for a financial bailout. The government was already in office and had to request the financial bailout against its original wishes. Finally, it acknowledged that it could not contain market pressure and in April 2011 requested a 75 billion grant to be paid between the EU ( 50 billion euros) and the IMF ( 25 billion). Again, massive austerity measures and social cuts were imposed following the bailout (Taibo 2018).

Arguing that the economic problems are caused by the increase in public debt as if states were to suspend payments is in fact the result of a disinformation campaign (Toussaint 2014). This discourse has been used to legitimise a set of social measures and policies aimed at redistributing wealth from the bottom up, causing an increase in inequalities and enabling the privatisation and mercantilisation of public services, as this has little to do with the economic problem that produced the debt (Stravrakakis 2013). In other words, the increase in public debt is mainly due to the crisis triggered mainly triggered by the excesses of private banks, construction companies and property developers, and by the bailout of those very banks (Toussaint 2014). As a consequence, the deficit and rising public debt have generated a new problem: the debt interest. Moreover, this situation may lead to a downward spiral like the one that many South American countries experienced in the 1990s (Piñero and Fresnillo 2013).

The management of the financial crisis shows, first of all, that sovereign power can enforce its demands on governments by pushing them to readjust their public budgets in order to bail out private banks, but also by imposing and constitutional as well as bank bailouts that grant "rights" and guarantee the repayment to creditors (Vasapollo et al. 2014) in a clear example of imperialism through debt (Graeber 2012). Debt is a key mechanism for creating a political relationship of dependence (Mbembe 2011). The burden of adjustment to get out of the crisis falls precisely on those countries on the periphery of the Mediterranean that are the main losers with the Eurozone's Economic and Monetary Union, despite the fact that these countries also produce more and more inequalities and that an emerging financial and rentier class is amassing greater economic and political power (Vasapollo et al. 2014). The adjustment policies imposed by the sovereign, although accepted by southern governments, are based on three main factors: a reduction in public spending (structural adjustment), a reduction in direct, indirect and deferred wages (structural reforms) and the provision of the necessary liquidity to banks (Vasapollo et al. 2014). The international financial institutions' reform rhetoric has been very similar since the Washington consensus: A State that intervenes less and less in the productive sphere so as to increase productivity and return on capital, reduce subsidies, open internal markets to foreign capital (Aglietta and Moatti 2002), under the false mantra of market efficiency. However, to claim that there is less intervention in the economy is just a fallacy; what has been done is to lay the foundations for a new cycle of accumulation (Tombs and Whyte 2015). Financial rescue programmes have been accompanied by severe austerity measures in the periphery, cuts in public investment and spending, market liberalisation and deregulation, privatisation of public companies and assets and wage reductions have been common recipes in these four countries (Lapavitsas 2013, Taibo 2018). These measures have aimed to underpin the EU's internal power regime, whilst protecting the stability of the banks and finances of the EU centre. At the same time, the EU's rationale of maintaining a 
strong centre with high competitiveness, a strong market and a current account surplus, as well as the potential for expansion of European financial capital, has been safeguarded (Lapavitsas 2012).

\section{Corporate exceptionality}

In this context of permanent exceptionality in Southern Europe the next case to be analysed is that of the corporations. Corporate power has reached such a degree that it has become a key player in politics, influencing and lobbying in the majority of political and legislative decisions (Ruggiero 2013). Without any doubt, today its power of influence is one of the greatest negations of democracy and popular sovereignty. Corporate criminality and its development cannot be disentangled from that of capitalist globalisation, being reflections of economic and political power and the contradictions of capitalism (Pearce 1976, Barak 2018). In this sense, the situation of permanent crisis in the south of Europe has been a laboratory for corporate power in implementing political measures and challenging the legislation operative before the crisis (Tombs and Whyte 2015). Certainly, the political influence of non-state agents has been enormous in recent decades as a result of their worldwide activities and growing wealth and power. Here we are not only referring to financial corporations (although they represent a prime example), but also to mineral, gas, petrol, agri-food or industrial companies. Many of these, once they have exhausted the possibilities of lobbying also resort to criminal activities as another way to obtain profits (Pearce 1976). When the contradiction between the accumulation of capital and obeying the law collide sometimes the latter wins as social legitimacy is crucial for governability. However, from a historical point of view the accumulation of capital triumphs in periods of crisis. Here we examine some of these quandaries in the context of the countries in the Southern European periphery.

In the preference share fraud, it can be seen how the Spanish state made it possible for financial institutions, in a context of global liquidity shortage, to sell a financial product which was unsuitable for small investors (Missé 2013) on a huge scale. This financial product was designed to increase the banks' capital ratio. The Spanish state delegated to the regulatory agencies, the Bank of Spain and National Securities and Exchange Commission, the protection of these investors, but they failed to protect them. When the banks used this product to resolve their liquidity problems, the regulatory agencies raised no objections, and thousands of people were affected by the fraud and regulatory failure (EFE 2014), but the breakdown in regulation did not entail any state intervention to remedy the situation.

Only after a significant social mobilisation did the state agree to establish arbitration between the banks and the defrauded consumers, however, it did not undertake any legal action against the banks or the regulatory agencies which had failed to carry out their legal obligations. This impunity guaranteed by the Spanish state worsened with the intervention of the European institutions and the European Memorandum (the Spanish bank bailout) signed by the European Commission and the Spanish state, which bolstered the impunity with acquittances of up to 60\% (Inurrieta 2013). This reveals that the European institutions are also responsible for the consolidation of corporate power in Europe, concealing the unequal relationship between corporations and citizens.

In Portugal the number of financial scandals has reached its full glory. All the financial organisations are affected by various cases of criminal activities: corruption, bribery, influence peddling and fraud. What would perhaps be more interesting is to analyse how the financial institutions when bankrupted and bailed out with public money have tried to escape from their civil and criminal responsibilities. For example, let us take the case of the Banco de Espirito Santo, perhaps that which, among the various Portuguese banks, stands out for its political and economic importance. In the times of debt crisis and liquidity shortage, it employed various fraudulent practices in order to increase its financial solvency. Thus, in Venezuela it used its clout from its business 
dealings with the Petróleos de Venezuela company to sell bonds worth 375 million dollars to the Banco de Desarrollo Económico y Social and to the Fondo de Desarrollo Nacional using falsified balance sheets. The fraudulent sale of junk bonds of which the bank was fully aware was made worse when the bank attempted to avoid any responsibility. Thus, once the financial situation of the bank caused its bankrupcy, in order to avoid payment of many of its liabilities the bank was divided into two parts: on the one hand, a "bad" bank (Banco Espirito Santo, BES) kept the toxic assets and the other, Nova Banco, kept the healthy assets (Martín del Barrio 2018). Retaining the toxic assets in the BES sought to make it insolvent and so leave the people and institutions that have claims against the bank without any chance of getting back their money and so consolidating a huge fraud.

In Italy we have seen how criminal networks along with big corporations ignored all the environmental regulations and controls leading to the rubbish crisis, which was particularly serious in Naples. The employers, with the help of criminal networks, employed various means to dump waste illegally, burying it in unauthorised areas, burning it or exporting it via ecological colonialism to countries with less environmental inspection. These networks also facilitated transport, invoices and fraudulent certificates. Sometimes this waste was highly toxic, something which has caused grave environmental and health problems. All this occurred with the connivance, in varying degrees, of politicians who benefited financially and politically. In this case, it can be seen that the need to maintain the rhythms of production trumps environmental protection, health and intergenerational justice (Ruggiero 2013). Environmental law and regulatory and sanctioning mechanisms are incapable of responding when faced with the necessity to accumulate profits, so leaving the majority of damage unpunished (Ruggiero and South 2010). At the same time, this impunity regarding legal compliance is exactly what incentivises circumventing it.

The case of the extractive companies is another good example of how the right to private gain reflects the enormous power of corporations. The situation regarding the Skouries mine demonstrates another of the multiple aspects of corporate impunity and bespoke legislation to facilitate business profits. Eldorado Gold is a Canadian company owning a mine in the north east of Greece and in which there are reserves of gold and copper. Initially, the permits for extraction were conceded in 2011, but the Syriza government rejected the permit in 2015 because environmental protection was not guaranteed in the company's plans with an open cast mine. The mine has caused a great deal of social opposition from the beginning of the project because of the ecological damage it occasions, but there is also severe repression against those who protest (Kouvelakis and Lapavitsas 2018). The company appealed against the decision in courts which finally decided in its favour. While the government demands environmental measures, the company is pressing the government to reach a better agreement for both so that the latter will obtain greater income so as to pay the high interests on the debt. Failing this, the mining company is threatening to take legal action against the Greek government because of the unnecessary permit delays and a loss of earnings of 750 million dollars. In this way, the corporation employs political pressure and commercial regulation to overturn environmental demands. Thus, regulation and legislation are factors that fail to prevent business activities which are harmful both socially and environmentally.

In these cases of corporate impunity, we can seem that there is no clear division between the state and big business. In fact, there is not a clash between public and private institutions, rather a symbiotic cooperation (Tombs 2012). The relationship between public and private agents, in the course of financialization, is better understand as the result of a political process which entails the concentration of class power producing a joining together of crime and corporate state damage (Bernat and Whyte 2017). Thus, in the struggle to finish with corporate victimisation it is just as important to demand compliance with the law as reversing the huge power of corporations, which is where laws are changed or breached (Barak 2018). As a result of this corporate power we can see that the impunity and favourable regulation are 
leading to the disappearance of big business crimes (Snider 2000) because there is no law enforcement or they are effectively decriminalized.

\section{Exceptionality in the southern border}

These Southern European countries, Portugal to a lesser extent logically, also play a fundamental role as gendarmes of the external border of the European Union. Their role is to make access difficult for migrants or refugees trying to enter the EU. The Southern European sea route is the most used by those seeking to enter the EU (Carr 2012). Racism is an institutional and institutionalised EU policy. The EU's policy towards migrants is a policy of death. The EU has power over the death of migrants. Migrants can be made to die without anyone having to justify themselves for it (Foucault 2012). The Mediterranean has become a large concentration camp where the right to asylum and life is abandoned. For migrants trying to cross the Mediterranean, death is the norm. For these migrants, life is the exception. Migrants are subjects of no rights, they are not entirely human, or perhaps the mere representation of the zoé, of the bare life, of those people who can be sacrificed without anyone having to answer for their deaths, they are killable (Agamben 1998). The refugee is today the representation of biopolitical power (Bazzicalupo 2010), the dark reverse of human rights, or perhaps simply the necropolitical face of the present moment. Biopolitics, understood as the political administration of life (Dean 2010), has the capacity to create subdivisions among humans. Foucault (2012) called this biopolitical capacity "racism", a technology that regulates the unequal distribution of death (Mbembe 2011), "the conditions of acceptability of giving death" (Foucault 2012). Racism is a form of politics that seeks to organize human coexistence in a context of antagonistic relations; it is an attempt to domesticate that relationship of opposition derived from colonialism (Sayyid 2017). The racist function of the state of giving death can be completed through exposure to death or by increasing the risk of death. Not only are they made to die in the Mediterranean, but they can also be shot with rubber bullets causing them to drown and no one is responsible for those deaths as happened in Tarajal. They can also be arbitrarily detained, in a ship for example, even putting their health at risk. They may be denied aid or even prevented from docking at a port in a process in which these states compete to be the cruellest. The police protect the border, particularly in Spain's colonial enclaves in Africa, which have become no-right spaces for migrants and where colonial police violence, be it European or the gendarmes of African countries, not only goes unpunished, but reminds us that we are still in a world where the violent hierarchy of the division between Western Europe and Africa still structures the world. Racism, like colonialism, is linked to the consolidation of an international order, to a world system (Sayyid 2017). The colonial order still distributes the right to live and die unequally. In the colony and for the colonized subjects, power still operates outside the law, it is a force of no-right, of indistinction between norm and exception, between peace and war (Mbembe 2011). The refugee crisis has served to strengthen the European Union's area of influence in third countries by signing agreements that externalize the control of migration to third countries outside the EU (Carr 2012). It has served to redefine the peripheral centre dynamics for implementing the EU agenda for migration. The control of space is the first matter of sovereignty. The refugee crisis has been the discourse that has allowed for the intensification of the control over the countries that supposedly are part of the refugees' route. Not in vain, the refugee crisis is the distillation of centuries of colonial enterprises (Karmy 2016). EU sovereignty over these countries means control of space, with indirect control exercised by these countries themselves in the interests of the EU. These territorialised power relations at the service of the EU reproduce all migration control devices outside the EU in an aggravated way: police, detention centres, expulsion, abandonment. Control over colonised subjects is also exercised indirectly by the EU, extending beyond its borders. The control of people over rights is once again being prioritised, the violation of rights for migrants being the norm in many countries outside the EU as well. Again, the ability to create population subdivisions is 
reproduced outside the EU and by EU mandate. In this way, racialised social relations are reconfigured (Bonilla-Silva 1999), racialization is intensified. Again, we are faced with different rights for legally constructed categories of people (Mbembe 2011). If the sovereign right to kill in the colonies is not subject to rules, by outsourcing the border the EU is liberating the right to kill. It is a power that is not concerned with the administration of life (Dean 2010), but one that subordinates life to a policy of death (Mbembe 2001). It is a necropolitical power exercised indirectly. "The colonies are the place par excellence where the controls and guarantees of the judicial order can be suspended, where the violence of the state of exception supposedly operates in the service of "civilization'"' (Mbembe 2011).

This regime of European necropower that takes place outside its borders is also projected towards the interior. That is to say, necropolitics occurs both in an interregional and intraregional way. In this intra-European expression, a good example to understand the close relationship between the EU and racism as a state policy is the one between the EU and the foreign policy of the member states. Thus, in the very same month that Spain joined the EU, it also passed its first Aliens Act in 1985. The approval of this law was part of Spain's negotiations to join the EU (Calavita and Suárez-Navas 2003). In other words, the evolution of immigration laws goes hand in hand with the European integration process and project. The EU has been increasing its efforts to coordinate in matters of immigration with various programs like Eurosur, Eurodac, VIS or SIS I and $1 \mathrm{I},{ }^{1}$ common agencies such as Frontex or financing devices such as $\operatorname{SIVE}^{2}$ (Carr 2012, Jansen 2017). The law on foreigners meets two explicit objectives: to guarantee the rights of those in a regular administrative situation (particularly those immigrants from the rest of the EU) and to control illegal immigration by establishing the possibility of creating a series of measures to manage the migrant population (sanctions, detention centres, deportations). The consequence of the law, however, is to generate irregularity for the majority of the immigrant population residing in Spain. LOEX (Ley Orgánica de Extranjería) created the legal category of "immigrant" but also produced the category of "illegal" by default. A large number of migrants became irregular overnight. But, in addition, the construction of legal irregularity for the population of the countries of the global south is very difficult to escape because the regularity is always temporary and contingent, linked to the fulfilment of diverse requirements simultaneously. These requirements linked to the labour market make regularization difficult. The resulting irregularity is very difficult to avoid in a labour market as unstable and precarious as that of Southern Europe for its lower strata (Calavita 2005). Thus, it seems that along with institutional racism there is also an economic rationale in the construction of irregularity (Brandariz 2014). These migrants play an important role in low-productivity economies that require piecework and, therefore, the lesser the rights of the workers, the greater the benefit for the employers. The deportability of migrants is performative, it impels them to work (De Giorgi 2010). Deportability means exploitability. In other words, LOEX, excluding a large part of migrants from their rights, builds a flexible and vulnerable workforce ready to be exploited and without rights, maximizing business profits. In other words, the exclusion and vulnerability of migrants are the direct effect of the law, not an unpredictable reversal (Calavita 2005). This is one of the racist achievements as it divides the working classes of the southern countries into two groups, that of citizens and that of foreigners. The former have rights, access to welfare programs, union representation, dialogue with the state and its administrations. The latter suffer police persecution, stigmatisation, racialisation, abuse, stark exploitation and death at the border (Melossi 2015). The law on foreigners thus produces a division within the working classes that reinforces social relations of domination and fractures horizontal

\footnotetext{
${ }^{1}$ Eurosur is the European External Surveillance System, Eurodac is the European Dactyloscopy, SIS I and II is the Schengen Information System I and II and VIS is the Visa Information System.

2 It is a surveillance system that uses CCTV cameras and a radar system to detect migrant boats in the waters of the Strait of Gibraltar, and which is co-funded by the EU.
} 
solidarity. For the former there is a liberal relationship of individual demands with respect to the state; for the latter there is clandestinity (Calavita and Suárez-Navas 2003). The reproduction of docile migrant diasporas through law and repression in Europe facilitates the ongoing colonization of the South.

\section{Discussion: Abandoning Democracy}

Criticism of formal democracy has always stressed that it is a form without content, a technique of government (Agamben 2010) that can be filled with just anything. Racism, fascism, nationalism, patriarchy, capitalism can fill this void. Even though there has always been a struggle to fill it with emancipatory content (Rancière 2010). On the other hand, the transit towards the state of exception as a dispositive of government marks the turn towards a formless content. The sovereign decides through the exception that whatever questions the regime of power is to be abandoned (Atiles 2016). It no longer matters that we vote in referendums against paying the debt (oxi in Greece), the constitution can be changed to ensure its payment (art. $135 \mathrm{EC}$ ), a non-elected technical cabinet can be imposed to appease the markets or budgets can be knocked down if they do not conform to the priorities of the European Union. Corporations must keep up the pace of profits (Tombs and Whyte 2015) even if social rights are continuously violated, while other dehumanized people are made to die at the border (Karmy 2016). In reality, under the guise of technical solutions, there are political solutions. These bogus solutions represent a deepening of a regime of capitalist and colonial power. This is where democracy becomes despotism, where democracy and totalitarianism overlap, where the state of permanent exception guarantees the triumph of corporate capitalism (Agamben 2004) in unequal intra-EU development (Amin 1986). The treatment given to the EU south shows how racist thinking is constructed within the EU. In the EU we see race wars (Foucault 2012).

If democracy is the opposite of despotism, a set of practices and institutions against the arbitrary exercise of power (Sayyid 2014), it is worth asking whether the EU and democracy in Southern Europe do not work or whether, on the contrary, they work perfectly but their objective is not to ensure human rights, popular will or the rule of law... If our objective is a government that gives priority to respect for the will of the people and the lives of all people, democracy and the EU will have to be abandoned. A decolonial interpretation (Mignolo and Walsh 2018) of democracy must provoke a shift in the hegemonic way of understanding democracy. A displacement in the definition of democracy, a displacement regarding who the democrats are, a displacement in the place where democracy is practiced. A challenge to the European power regime, which is what secures democracy and the EU. European democracy today requires the systematic violation of social rights, impunity for corporations and the death of migrants at the border.

In this sense, the category "pigs" has served to legitimise the subaltern position and unequal distribution of power within the EU, to build a racializing ontology. It allows us to be left out of history, like an empty and flat land that has to be put at the service of certain economic and political interests. At the same time, it makes it possible to introduce a caesura among European citizens. There are no longer just Europeans, there are good Europeans and there are Southern Europeans. Within the European Union, we note that this colonialism is based on three intertwined issues. There is a racist ontological view of the south (PIGS), there is an economic project (corporate financialisation), and there is also a colonial power relationship with its non-EU neighbours (necropolitics). The "pigs" is the category that allows us to question the Europeanness of the countries of the south and, therefore, allows them to punish ourselves with economic measures for our vagrancy and corruption. The punishment of Southern Europe stems from an orientalist outlook and a civilizing mission. Pigs give coherence and expel broken pieces from the EU. It is not the EU that is wrong, nor is capitalism in its neoliberal form. No, it is backward southerners that are wrong. What we really have is a geopolitical and economic victory translated 
into cultural terms that legitimize and justify that victory. Austerity measures are also part of a political project that makes it possible to discipline ourselves in order to transform our subjectivity. We need to be neoliberalised in three different dimensions. Temporarily, we are not Europeans because we are lagging behind, underdeveloped. Spatially, we are not fully European, we are the southern periphery of the EU. Subjectively, we do not share the right values of hard work and honesty. Within the EU, not all territories, not all bodies are equal. The southern periphery is backward, outward and inferiorised (Sayyid 2014).

At the same time as forging an image of the southern periphery as backward, an image of progress and efficiency of the centre of the EU is being forged by opposition. The geo-economic centre of the EU is a universal standard to be resembled or imitated. The level of backwardness is measured by this distance to the centre. Again, as in the Hegelian philosophy of history, German political and economic power continues to be the core that shapes the time and history of the EU. Political and economic power radiates from this core. The North-European identity is also constructed in opposition to that of the south (weak, lazy, corrupt), the success of the North is verified through the defeat of the south. A tragic south that does not escape its destiny. We are a problem for the Europeans of the geo-economic centre, we make public deficit, sovereign debt, corruption soar. We have to change culturally if we really want to be Europeans. The European identity is relational and contingent. Democratic identity is opposed to despotism. This sudden hatred for the inhabitants of Southern Europe, with various aggressions in the countries of the centre, has to be connected with the economic collapse and the fallacy of EU success. These racist practices are the result of the violent hierarchy within the EU. Southern pigs suddenly become people who do not learn from their history, who do not know what suits them politically, who vote wrong. The European centre does know what is good for them. The political is a heritage of the north while it essentialises the backward south and naturalises it as a different, inferior, racialised people. This colonialism within the EU dehistorizes conflicts turning them into a cultural, essential, natural issue (Sayyid 2017). Conflict is transformed into something natural, ethnic formations are reified and southerners who have no history have no politics either. The monopoly of those who write history is also the monopoly of those who make politics. There is no rule for those who make the rules, others have no choice but to obey those rules. Permanent exceptionality of the sovereign power that decides what happens in the south, when its legality is modified, when its rights are denied and when its governments are humiliated. The antagonism is evident between friends and enemies, introducing the political event. The EU is a capitalist and colonial matrix. Decolonising the EU means rewriting the history of the EU where the starting point is not the violent hierarchy between the centre and the periphery. Coloniality understood as a governmental rationale that is behind certain forms of colonialism and continues to structure a planetary hierarchy (Sayyid 2014), but also a European one.

However, the history of south and migrants resistance shows us that the history of the north is only one of the possible stories. That of the winners, but we can decentralise the EU and centre the Mediterranean in order to construct a nonneoliberal and anti-racist subjectivity. It is necessary to desubjectivise ourselves and to abandon European democracy in order to reconstruct a Mediterranean political space (Atiles 2016). An alliance of the north and south of the Mediterranean to build a Mediterranean political identity that dismantles the neoliberal Europeanisation of our subjectivity.

\section{Conclusions: Democracy abandoned}

In this paper we have argued that the cases under scrutiny represent three examples (public debt, corporations and southern border) of a permanent state of exception that are a part of a strategy of political and geo-economic domination. This is a class and colonial project that defines the power regime born out of the integration of these 
countries into the spatial arrangement of the European Union (Aglietta and Brandt 2015), even though this power regime has an endogenous transposition within each of these countries. The formative conditions of this permanent exceptionality have been reached precisely by the set of measures taken by the European Union and the different states of the peripheral south. Each and every one of the different administrative bodies has played a role that has led to this situation. That is why, without the slightest doubt, we can say that directive by directive, program by program, measure by measure, regulation by regulation, law by law, this power regime has been forged. In this regime it is clear that the nation-state is an integral part of the governing mechanism which constitutes the state of exception. However, this dispositive has become more and more pervasive in the process of financialization of the economy, where corporations have been gaining institutional weight in the provision of services and rights, continuously fencing the old and new commons. This process of corporate empowerment makes it easier for the formal constitution to be materially bent by corporate power (Bernat and Whyte 2015).

Exceptionality in the European power regime has occurred in three distinct spheres. First, in the public debt, which is the result in great part of the private debt, constitutionalised to assure its payment even if the population shouts out "OXI". Second, impunity for corporations, whether for financial institutions and other extractive, service, agri-food or industrial companies with custom-made regulations, legislation and impunity. Third, death on the southern border, and the spread of state racism and legal othering that denies human rights, causing direct return of migrants, lock-ups in boats, police brutality or saturated refugee camps. These are three forms of despotism in the EU, of denial of rights, of the popular will and of an enforced sovereign power so as to guarantee a regime of capitalist and colonial power. In situations of crisis when the discreet charm of ideology and the media fails, then the devices of sovereign power appear. The Troika, the International Monetary Fund, the European Commission or the European Central Bank appear to force the southern barbarians to modernize by means of adjustments and cuts, by cutting pensions, social benefits and the most basic rights and by privatising all public goods and assets.

In our analysis of the creation of public debt and the sovereign debt crisis, we have noted how international capital rights are safeguarded. This case of reconversion of private debt into public debt allows us to guarantee corporate impunity, in other words, to close the circle of the regime of permissiveness. In this sense, the constitutionalisation of the debt and the rights of international capital are a key element to guarantee one more time the European power regime and establish a new post-crisis spatial arrangement that allows for a new cycle of accumulation through austerity measures and of rights re-marketing, through the loss of social rights and through indirect wages regardless of the collective suffering these measures entail. The case of the public debt shows us that the relationship between State and corporation is constantly evolving, making the social arrangement to be in a process of constant updating, where social forces struggle to impose a settlement favourable to their interests, but in this case one that favours the consolidation of the unequal relationship between centre and periphery. So, the European institutions and the southern states are a fundamental part of the financialization of the economy, safeguarding the continued subordination of the south of the EU and the Germancentred power regime (Krugman 2012). At the same time, the conditions of possibility for a new cycle of capital accumulation are established (Aglietta 1979, Whyte 2014).

In addition, we have seen how corporate exceptionality and the crimes of the powerful are an unequivocal demonstration of the fallacy of market efficiency and the corporations' effectiveness in their management. This discourse claims that these are necessary for the economic success of society and tries to hide the deep connections of corporations with the State, the intrinsic dependence between both institutions that are continuously reinforced (Tombs and Whyte 2015). Precisely, this symbiotic 
relationship masks the social relations underlying the state and the corporation. This new post-crisis arrangement produces law: modifying laws, changing the constitution, creating a new regime of capital accumulation, that is, permission for corporations and their crimes, which increases corporate power (Whyte 2014). This new arrangement is the result of the abuse of corporate power, but it continues to increase and concentrate greater power, thus ensuring that new corporate abuses are perpetuated and reactualized. But the abuse of corporate power not only refers to criminal practices aimed at increasing profit, but also extends to corporate impunity, so that it does not even matter if the practices employed are within the law. In the case of the preferred shares scam and waste of management we see that these are corporations that are too powerful to be punished (Pontell et al. 2014). No one is surprised since there have hardly been legal cases against the banks for their wrongdoing as the rebalancing that took place with the financialization turned them into too powerful actors. Thus, the seizure of law by corporate Europe gives total impunity of corporations. Therefore, we can affirm that the political economy of the crimes of the powerful is the reverse of the political economy of the non-punishment for the crimes of the powerful. This form of capital accumulation is devastating the communities of Southern Europe with the disappearance of productive work, which severely impacts the lives of the working classes of these countries (Taylor 1997), as the economic geography points out (Krugman 1992). It is the populations of these disadvantaged countries in the new European space arrangement - from the entry into force of the Economic and Monetary Union to the new post-crisis settlement who are the most harshly hit by these attacks of corporate power in the EU (Lapavitsas 2013, Aglietta and Brandt 2015).

Finally, the situation of the migrant people and the exceptionality on the southern border show us how EU racism has turned the Mediterranean into a death camp. Racism is a state policy in the south of the EU, but also in the whole of the EU. Policies, agencies, laws, police, prisons, camps and a host of other power devices bear witness to it. The securisation of the border has become a European priority (J ansen 2017), aware of its privilege and of the violence necessary to guarantee that way of life that does not seem to be available to everyone. Thus, by imposing restrictions on entry and making access more difficult, conditions of death are being created for people trying to reach Europe. The countries of the south have become mere guardians of a vital space that is denied to others, to the aliens, which can be made to die in order to protect this space (Foucault 2012). State racism is a policy of death, of direct death of migrants or one that can be caused by hindering them access, which increases the risk of death. This necropolitics is a government technology used to instil the power of death mostly in the constituent exterior of the EU: its southern neighbours. Racism allows for an unequal distribution of the possibility of death (Mbembe 2011). This racism cannot be separated from the violent global hierarchy that divides the different countries (Sayyid 2017), nor from the centuries of European colonialism (Karmy 2016). But racism does not remain on the external border of the EU but permeates all social relations within countries with the legal construction of irregularity and otherness, causing a division within the popular classes and hindering horizontal solidarity (Calavita 2005).

In this way, we have analysed how the permanent state of exception is the device that guarantees a regime of power within the EU to maintain relations of domination and subordination between centre and periphery in the present time. The state of exception allows the introduction of the political dimension into the legal order and thus imposes the sovereign decision (Atiles 2016). The state of exception is the device that allows the domination and reproduction of the power regime. However, the effects of this European power regime are also projected on the outside of the EU as could not be otherwise with a colonial power that violates its constitutive outside. The state of emergency enshrines capitalist, corporate and colonial domination while legalizing the violence necessary to maintain power relations. These relations are in a continuous process of reactualisation, never fully solidified, always 
partially disputed. In order to subvert them it is a central task to understand the sovereign power and its governing devices in order to insert the political fact and decide on the exception.

\section{References}

Agamben, G., 1998. Homo Sacer. El poder soberano y la nuda vida. Trad.: A. Gimeno. Valencia: Pre-Textos.

Agamben, G., 2004. Estado de excepción. Trad.: A. Gimeno. Valencia: Pre-Textos.

Agamben, G., 2010. Notas preliminares sobre el concepto de democracia. In: J. Bassas Vila, dir., Democracia en suspenso. Madrid: Casus Belli.

Agamben, G., 2014. Archeologia della Politica. Seminar at University of Girona, May.

Aglietta, M., 1979. Regulación y crisis del capitalismo. Madrid: Siglo XXI.

Aglietta, M., and Brandt, T., 2015. Un New Deal para Europa. Crecimiento, euro, competitividad. Madrid: Traficantes de Sueños.

Aglietta, M., and Moatti, S., 2002. El FMI: del orden monetario a los desórdenes financieros. Madrid: Akal.

Amin, S., 1986. El desarrollo desigual. Barcelona: Planeta.

Amin, S., 1997. El capitalismo en la era de la globalización. Barcelona: Paidós.

Atiles, J., 2016. Apuntes para abandonar el derecho: estado de excepción colonial en Puerto Rico. Cabo Rojo: Educación Emergente.

Balestrini, N., and Moroni, P., 2006. La horda de oro. La gran ola revolucionaria y creativa, política y existencial (1968-77). Madrid: Traficantes de Sueños.

Barak, G., 2018. Unchecked Corporate Power: Why the Crimes of Multinational Corporations Are Routinized Away and What We Can Do About It. London: Routledge.

Bazzicalupo, L., 2010. Biopolítica: un mapa conceptual. Santa Cruz de Tenerife: Melusina.

Benjamin, W., 2010. Crítica de la violencia. Madrid: Biblioteca Nueva.

Bernal, C., 2014. Daños sociales y delitos estatal-corporativos en la crisis europea. In: I. Rivera, ed., Delitos de los estados, mercados y daño social. Barcelona: Anthropos, 113-129.

Bernat, I., 2018. The crimes of the powerful and the Spanish crisis. In: S. Bittle et al., eds., Revisiting the Crimes of the Powerful: Marxism, Crime and Deviance. London: Routledge.

Bernat, I., and Whyte, D., 2015. Entendiendo los orígenes del crimen estatalcorporativo: un análisis de los desastres del Prestige y Morecambe Bay. Revista Crítica Penal y Poder, 9 (1), 255-278.

Bernat, I., and Whyte, D., 2017. State-corporate crime and the process of global accumulation: mapping a global regime of permission from Galicia to Morecame Bay. Critical Criminology [online], 25 (1), 71-86. Available from: https://doi.org/10.1007/s10612-016-9340-9 [Accessed 27 November 2018].

Bonilla-Silva, E., 1999. The essential social fact of race. American Sociological Review [online], 64 (6), 899-906. Available from:

https://doi.org/10.2307/2657410 [Accessed 27 November 2018].

Brandariz, J.A., 2014. El gobierno de la penalidad La complejidad de la política criminal contemporánea. Madrid: Dykinson. 
Brown, W., 2015. El pueblo sin atributos: la secreta revolución del neoliberalismo. Trad.: V. Altamirano. Barcelona: Malpaso.

Calavita, K., 2005. Immigrants at the Margins: Law, Race and Exclusion in Southern Europe. Cambridge University Press.

Calavita, K., and Suárez-Navas, L., 2003. Spanish immigration law and the construction of difference: citizens and "illegals" on Europe's Southern border. In: R. Warren Perry and B. Maurer, eds., Globalization Under Construction. Governmentality, Law, and Identity. Minneapolis: University of Minnesota Press.

Campesi, G., 2011. Soggetto, disciplina, governo: Michel Foucault e le tecnologie politiche moderne. Milan: Mimesis.

Campesi, G., 2018. Crisis, Migration and the Consolidation of the EU Border Control Regime. International Journal of Migration and Border Studies [online], 4 (3), 196-221. Available from: https://doi.org/10.1504/I] MBS.2018.093891 [Accessed 27 November 2018].

Carr, M., 2012. Fortress Europe: Inside the war against immigration. London: Hurst.

Cooper, V., and Whyte, D., 2017. Introduction: the Violence of Austerity. In: The Violence of Austerity. London: Pluto.

Cutillas, S., and Wessling, U., 2013. La deuda en España. In: Plataforma Auditoría Ciudadana de la Deuda (¡No debemos!, ¡no pagamos!, coord.), ¿Por qué no debemos pagar la deuda? Razones y alternativas. Barcelona: Icaria.

De Giorgi, A., 2010. Immigration control, post-fordism and less eligibility. A materialist critique of the criminalization of immigration across Europe. Punishment and Society [online], 12 (2), 147-167. Available from: https://doi.org/10.1177\%2F1462474509357378 [Accessed 27 November 2018].

Dean, M., 2010. Governmentality: Power and Rule in Modern Society. London: Sage.

Dussel, E., 2016. Filosofías del sur: descolonización y transmodernidad. Madrid: Akal.

EFE, 2014. Un jurista advierte de que la venta de preferentes fue una estafa a "gran escala". El País [online], 10 February. Available from: https://elpais.com/economia/2014/02/10/actualidad/1392049289_426430.ht ml [Accessed 15 August 2018].

El Mundo, 2011. Zapatero y Rajoy pactan reformar la Constitución para limitar el déficit. El Mundo [online], 23 August. Available from: https://www.elmundo.es/elmundo/2011/08/23/espana/1314089107.html [Accessed 10 June 2018].

Fleisner, P., 2015. La vida que viene: estética y filosofía en el pensamiento de Giorgio Agamben. Buenos Aires: Eudeba.

Fontana, J., 2011. Por el bien del imperio: una historia del mundo desde 1945. Barcelona: Pasado y presente.

Foucault, M., 2012. Cal defensar la societat. Barcelona: Proteus.

Friedrichs, D., 2018. Crimes of globalization and Asian dam projects: powerful institutions and slow violence. In: S. Bittle et al., eds., Revisiting the Crimes of the Powerful: Marxism, Crime and Deviance. London: Routledge.

Friedrichs, D., and Friedrichs, J., 2002. The World Bank and the Crimes of the Globalization: a Case Study. Social Justice, 29 (1-2), 13-36. 
Georgoulas, S., 2018. Grecia: crimen-estatal corporativo en la época de los memorandos. Revista crítica penal y poder, № 14, 5-21.

Graeber, D., 2012. En deuda: una historia alternativa de la economía. Trans.: J. Andreano Weyland. Barcelona: Ariel.

Guareschi, M., and Rahola, F., 2011. Chi decide? Critica della ragione eccezionalista. Verona: Ombre Corte.

Inurrieta, A., 2013. Una estafa piramidal y consentida. Alternativas económicas, 1, March, 13-14.

Jansen, F., 2017. Smarters borders. Challenges and limitations of data-driven borders. In: M. Gržinić, ed., Border Thinking: Disassembling Histories of Racialized Violence. Publication Series of the Academy of Fine Arts Vienna, vol. 21. Sternberg Press.

Karmy, R., 2016. Escritos bárbaros: ensayos sobre razón imperial y mundo árabe contemporáneo. Santiago de Chile: LOM.

Knox, R., 2017. Legalising the violence of austerity. In: V. Cooper and D. Whyte, eds., The Violence of Austerity. London: Pluto.

Kouvelakis, S., and Lapavitsas, C., 2018. Grècia: el gir repressiu de Syriza. Jornada, 13 October.

Krugman, P., 1992. Geografía y comercio. Barcelona: Bosch.

Krugman, P., 2012. ¡Acabad ya con esta crisis! Trans.: C. Balza and G. García. Barcelona: Crítica.

Lapavitsas, C., 2012. Crisis en la eurozona. Trans.: C. Campos. Madrid: Capitán Swing.

Lapavitsas, C., 2013. Profiting Without Producing: How Finance Exploits Us All. London: Verso.

Lemke, T., 2011. Biopolitics: an advanced introduction. Trans.: E.F. Trump [online]. New York / London: New York University Press. Available from: http://ieas. unideb. hu/admin/file_7425.pdf

Martín del Barrio, J., 2018. Novo Banco, el "banco bueno" del Espirito Santo, pierde 1.400 millones. El País [online], 28 March. Available from: https://elpais.com/economia/2018/03/28/actualidad/1522255785_475704.ht ml [Accessed 3 August 2018]

Mbembe, A., 2001. On the Postcolony. Oakland, CA: University of California Press.

Mbembe, A., 2011. Necropolítica. Trans.: E. Falomir Archimbault. Santa Cruz de Tenerife: Melusina.

Melossi, D., 2015. Crime, Punishment and Migration. London: Sage.

Mignolo. W., and Walsh, C., 2018. On Decoloniality: Concepts, Analytics, Praxis. Durham, NC / London: Duke University Press.

Missé, A., 2013. Atrapados en la gran ratonera de las preferentes. Alternativas económicas, 1, March, 9-11.

Panayotov, S., 2017. Necropolitics in the East. In: M. Gržinić, ed., Border Thinking: Disassembling Histories of Racialized Violence. Publication Series of the Academy of Fine Arts Vienna, vol. 21. Sternberg Press.

Pearce, F., 1976. Crimes of the Powerful: Marxism, Crime and Deviance. London: Pluto. 
Piñero, G., and Fresnillo, I., 2013. La deuda en el mundo. In: Plataforma Auditoría Ciudadana de la Deuda (¡No debemos!, ¡no pagamos!, coord.), ¿Por qué no debemos pagar la deuda? Razones y alternativas. Barcelona: Icaria.

Pontell, H., et al., 2014. Too big to fail, too powerful to jail? On the absence of criminal prosecutions after the 2008 financial meltdown. Crime, Law and Social Change [online], 61 (1), 1-13. Available from: https://doi.org/10.1007/s10611-013-9476-4 [Accessed 27 November 2018].

Rancière, J., 2010. Las democracias contra la democracia. In: Democracia en suspenso. Madrid: Casus Belli.

Ruggiero, V., 2013. I crimini dell'economia. Una lettura criminologica del pensiero economico. Milan: Feltrinelli.

Ruggiero, V., and South, N., 2010. Green criminology and dirty collar crime. Critical Criminology, 18, 251-262.

Said, E., 2002. Orientalismo. Trans.: M.L. Fuentes. Barcelona: Mondadori.

Sayyid, S., 2014. Recalling the Caliphate: Decolonization and World Order. London: Hurst.

Sayyid, S., 2017. Post-racial paradoxes: rethinking European racism and antiracism. Patterns of Prejudice [online], 51 (1), 9-25. Available from: https://doi.org/10.1080/0031322X.2016.1270827 [Accessed 27 November 2018].

Schmitt, C., 1991. El concepto de lo político. $1^{\text {st }}$ ed. Madrid: Alianza.

Schmitt, C., 2009. Teología política. Madrid: Trotta.

Snider, L., 2000. The Sociology of Corporate Crime: an Obituary (Or: Whose Knowledge Claims have Legs?). Theoretical Criminology [online], 4 (2), 169206. Available from: https://doi.org/10.1177\%2F1362480600004002003 [Accessed 27 November 2018].

Stravrakakis, Y., 2013. La sociedad de la deuda. Grecia y el futuro de la postdemocracia. In: A. Badiou et al., El síntoma griego. Trans.: J. Palacio Tauste, A. Fornet Vivancos. Madrid: Errata naturae.

Taibo, C., 2018. Comprender Portugal. $2^{\text {nd }}$ ed. Madrid: Los libros de la Catarata.

Taylor, I., 1997. The political economy of crime. In: M. Maguire, R. Morgan and R. Reiner, eds., The Oxford Handbook of Criminology. $2^{\text {nd }}$ edition. Oxford University Press, 265-303.

Tombs, S., 2012. State-Corporate Symbiosis in the Production of Crime and Harm. State Crime, 1 (2), 170-195.

Tombs, S., and Whyte, D., 2015. The Corporate Criminal: Why Corporations Must Be Abolished. London: Routledge.

Toussaint, E., 2014. Bancocracia. Barcelona: Icaria.

Vasapollo, L., Martufi, R., and Arriola, J., 2014. El despertar de los cerdos: PIIGS, Portugal, Irlanda, Italia, Grecia, España. Trans.: R. Conde. Madrid: Maia.

Vilar, P., 1984. Història d'Espanya. Barcelona: Crítica.

Whyte, D., 2014. Regimes of permission and State-corporate crime. State Crime J ournal [online], 3 (2), 237-246. Available from:

https://doi.org/10.13169/statecrime.3.2.0237 [Accessed 27 November 2018].

Whyte, D., 2015. How Corrupt is Britain? London: Pluto. 